\title{
Kepemimpinan dan Pengambilan Keputusan Terhadap Kinerja Karyawan PT. Kaldu Sari Nabati
}

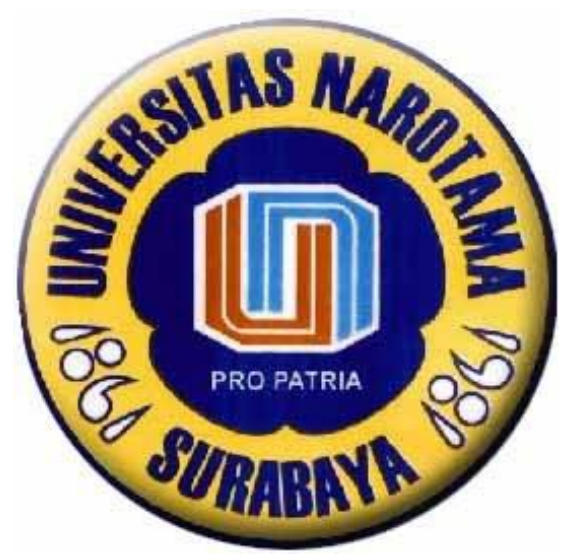

Disusun oleh :

Fia Afifatuz Zuhriah (01214043)

Fia.narotama@gmail.com

Lutfiana Rose (01214023)

Phyluck10@gmail.com

FAKULTAS EKONOMI DAN BISNIS UNIVERSITAS NAROTAMA

J1. Arief Rachman Hakim No.51 Surabaya

Phone : 031-5946404- 5995578, fax. 031- 5931213

www.narotama.ac.id 2018 


\section{PENDAHULUAN}

\subsection{Latar Belakang}

Pengambilan keputusan merupakan tindakan manajemen dalam mencapai sasaran. Teori pengambilan keputusan memiliki unsur-unsur utama berupa pembuat keputusan dihadapkan pada suatu masalah tertentu yang dapat diperbandingkan satu sama lain, Tujuan-tujuan, nilainilai atau sasaran yang mempedomani pembuat keputusan amat jelas dan dapat ditetapkan tingkatannya sesuai dengan urutan pentingnya. Berbagai alternatif untuk memecahkan masalah tersebut diteliti secara seksama. Akibat-akibat yang ditimbulkan oleh setiap alternatif yang dipilih dengan teliti. Setiap alternatif dan masing-masing akibat yang menyertainya dapat dibandingkan dengan alternatif-alternatif lainnya serta pembuat keputusan akan memilih alternatif dan akibat-akibatnya yang dapat memungkinkan tercapainya tujuan, nilai atau sasaran. Dengan banyaknya alternatif yang mempengaruhi sebuah keputusan maka sulit untuk mengambil sebuah keputusan secara manual.

\subsection{Rumusan Masalah}

1. Bagaimana fungsi dan tujuan pengambilan keputusan pada PT. Kaldu Sari Nabati ?

2. Bagaimana cara Manager memotivasi kinerja karyawan PT. Kaldu Sari Nabati ?

3. Bagaimana Proses pengambilan keputusan?

\subsection{Tujuan}

1. Mengetahui fungsi dan tujuan pengambilan keputusan.

2. Mengetahui cara mengevaluasi kinerja karyawan.

3. Mengetahui proses pengambilan keputusan. 


\section{TINJAUAN PUSTAKA}

Dalam kehidupan sehari-hari kita selalu dihadapkan dengan istilah organisasi

Organisasi bisnis biasanya bertujuan untuk mencari keuntungan finansial, organisasi kemasyarakatan biasanya bertujuan untuk tujuan kemasyarakatan, organisasi politik biasanya untuk tujuan kekuasaan dan organisasi keagamaan biasanya untuk tujuan misi atau dakwah.Tujuan tersebut menurut AsakuWalisongo (2013) dicerminkan oleh sasaran yang harus dilakukan baik dalam jangka pendek, maupun jangka panjang.Implementasinya setiap organisasi merumuskan visi, misi, serta tujuan baik jangka pendek, menengah maupun jangka panjang.

Setiap organisasi tentu memiliki pemimpin dan kepemimpinan.Biasanya pemimpin memiliki pengaruh lebih besar dalam upaya pencapaian tujuan organisasi, oleh karena pemimpin sering diistilahkan dengan orang yang mempengaruhi bawahan untuk mencapai tujuan yang diharapakan. Pendapat itu sejalan dengan yang disampaikan olehHusaini Usman (2013 : 312), kepemimpinan ialah ilmu dan seni mempengaruhi, orang atau kelompok untuk bertindak seperti yang diharapkan untuk mencapai tujuan secara efektif dan efisien. Jadi jelas bahwa pemimpin memiliki pengaruh besar terhadap sukses tidaknya sebuah oraganisasi.

Salah satu fungsi yang harus dilakukan pemimpin dalam upaya pencapaian tujuan adalah bagaimana pemimpin itu bisa mengambil keputusan dengan efektif.Dalam realita pengambilan keputusan bukanlah hal yang sedernana, sebab setiap pengambilan keputusan biasanya mengandung dua konsekuensi sekaligus baik konsekuensi positif maupun konsekuensi negatif. Namun demikian seorang pemimpin harus berani mengambil keputusan dari beberapa pilihan yang dihadapai. Seorang pemimpin diharapkan mengikuti pendapat Terry dalam Marzuki (2015 : 2), bahwa dalam mengambil keputusan hendaklah memilih yang terbaik dari berbagai altenatif yang tersedia. Salah satu tugas terpenting seorang pemimpin adalah untuk menentukan yang terbaik bagi organisasi dan para anggotanya.Namun dalam mengambil keputusan, terkadang pemimpin pun menghadapi dilema dan seolah berada di persimpangan jalan. 
Kecepatan dan ketepatan seorang pemimpin dalam mengambil keputusan lazimnya menjadi tolak ukur kompetensi dan kredibilitas yang dimilikinya. Jika pemimpin lamban dan ragu-ragu dalam bertindak, anak buah akan melihat bahwa pemimpin tersebut adalah pemimpin yang tidak berani mengambil resiko. Terbiasa cepat dalam pengambilan keputusan memang bukan pekerjaan mudah, butuh rasio yang jernih dan intuisi yang tajam agar bisa menghasilkan keputusan yang tepat.Menarik untuk dikaji bagaimana seorang pemimpin bisa mengambil keputusan dengan baik, dalam pengertian efektif, efisien, meminimalkan resiko, serta bermanfaat bagi kemajuan organisasi dalam rangka pencapaian tujuan yang diharapkan.

\section{Pengertian Pengambilan Keputusan}

Drommond (1985) berpendapat bahwa pengambilan keputusan merupakan usaha penciptaan kejadian-kejadian dan pembentukan masa depan (peristiwa-peristiwa pada saat pemilihan dan sesudahnya). Pendapat ini menegaskan bahwa pengambilan keputusan merupakan proses pada saat sejumlah langkah yang harus dilakukan dengan pengevaluasian alternatif untuk membuat putusan dari semua alternatif yang ada (Syaruddin:48).

dari beberapa definisi dijelaskan di atas, maka disimpulkan bahwa pengambilan keputusan adalah proses pemecahan masalah dengan menentukan pilihan dari beberapa alternatif untuk menetapkan suatu tindakan yang ingin dilakukan dalam mencapai tujuan yang diinginkan.

Pengambilan keputusan dengan kreatif dan inovatif.

Pengambilan keputusan dengan tidak kreatif mempunyai kecenderungan untuk membuat keputusan secara emosional. Dengan menggunakan kreativitasnya, pengambilan keputusan dapat menemukan alternatif-alternatif untuk memecahkan masalah, kemudian memilih salah satu alternatif yang bermanfaat bagi pencapaian organisasi. Inovasi memungkinkan pengambilan keputusan melaksanakan keputusan dengan baik.

Berdasarkan jenis problemnya dikelompokkan menjadi:

Pengambilan keputusan terprogram, yaitu pembuatan keputusan dapat dilakukan dengan menggunakan standar prosedur operasi rutin. Cirinya adalah:

Problemnya terstruktur, sederhana dan informasinya tersedia lengkap. 
Problem dan proses pembuatan keputusannya sudah berulang-ulang terjadi sehingga sudah dapat diperhitungkan dan mempunyai pengalaman menyelesaikannya.

Pengambilan keputusan tidak terprogram ialah pengambilan keputusan yang problemnya unik, belum pernah terjadi. Informasi mengenai problem belum tersedia atau sedikit,peraturan, kebijakan, prosedur operasi standar untuk membuat keputusan yang belum ada. (Wirawan, 2014:556).

Pengaruh Pengambilan Keputusan yang Efektif bagi Kemajuan Organisasi

Sebagai mana yang telah dipaparkan oleh Usman, Husaini (2013 : 312), bahwa kemajuan suatu organisasi dipengaruhi oleh cara pemimpin dalam mengambil keputusan. Telah dilakukan beberapa penelitian yang searah dengan pendapat Usman (2013) tersebut.Juliyanti, Mohammad Isa Irawan, dan Imam Mukhlash (2011) melakukan penelitian tentang Pemilihan guru Berprestasi menggunakan metode AHP-TOPSIS. Penelitian tersebut menghasilkan temuan yaitu adanya suatu sistem pengambilan keputusan dapat membantu proses pemilihan berdasarkan kriteria-kriteria yang ditentukan sehingga bisa dilakukan proses perhitungan yang lebih efektif dan efesien. 


\section{METODE PENELITIAN}

Dalam kaitan ini Arief Furchan (1999: 22) menerangkan sebagai berikut: Metode kualitatif ialah "proses penelitian yang menghasilkan data deskriftif, ucapan atau tulisan atau perilaku yang dapat diamati dari orang-orang itu sendiri, menurut pendapat kami pendekatan ini langsung menunjukan setting dan individu-individu dalam setting itu secara keseluruhan. Subyek penyelidikan baik berupa organisasi atau individu tidak mempersempit menjadi variable yang terpisah atau menjadi hipotesa melainkan dipandang sebagai suatu keseluruhan. Dari pendapat diatas, dapat dikatakan bahwa pendekatan kualitatif berusaha mendapatkan data deskriptif, ucapan atau tulisan dan perilaku yang dapat diamati.

Dalam penelitian ini digunakan pendekatan kualitatif dengan alasan mengacu pada beberapa alasan sebagai mana yang dikemukakan oleh. Margono (2000: 37) antara lain:

1. Untuk menanggulangi banyaknya informasi yang hilang, seperti yang dialami oleh penelitian kualitatif sehingga intisari konsep yang ada pada data dapat diungkap.

2. Untuk menaggulangi kecenderungan menggali data empiris dengan tujuan membuktikan kebenaran hipotesis akibat dari adanya hipotesis yang disusun sebelumnya berdasarkan berfikir deduktif seperti dalam pemikiran kuantitatif.

3. Untuk menanggulangi kecenderungan pembatasan variable yang sebelumnya, seperti dalam penelitian kuantitatif padahal permasalahan dan variable dalam masalah social sangat kompleks.

4. Untuk menanggulangi adanya indeks-indeks kasar seperti dalam penelitian kuantitatif yang menggunakan pengukuran enumerasi (perhitungan) empiris, padahal inti sebenarnya berada pada konsep-konsep yang timbul dari data.

Disamping alasan diatas, dalam peneitian ini digunakan pendekatan kualitatif disebabkan beberapa hal yang cukup penting antara lain: pertama, karena latar belakang penelitian tidak bersifat homogen, kedua, karena penelitian ini ingin mengungkap data dengan apa adanya sesuai 
dengan hasil temuan dilapangan tentang kepemimpinan manager pada TGA Bookstore Galaxi mal surabaya.

\section{Kehadiran Peneliti - Metode Penelitian}

Untuk mendapatkan data-data yang valid dan obyektif tehadap apa yang diteliti maka kehadiran peneliti dilapangan dalam penelitian kualitatif mutlak diperlukan. Kehadiran peneliti sebagai pengamat langsung terhadap kegiatan-kegiatan yang akan diteliti sangat menentukan hasil penelitian, maka dengan cara riset lapangan sebagai pengamat penuh secara langsung pada lokasi penelitian peneliti dapat menemukan dan mengumpulkan data secara langsung. Jadi dalam penelitian ini, insrtumen penelitian adalah peneliti sendiri yang sekaligus sebagai pengumpul data. Sedangkan instrument-instrumen yang lain merupakan instrument pendukung atau instrumen pelengkap oleh karena itu kehadiran peneliti dilapangan sangatlah diperlukan.

Adapun tujuan kehadiran peneliti dilapangan adalah untuk mengamati secara langsung keadaan-keadaan atau kegiatan-kegiatan yang berlangsung, fenomena-fenomena social dan gejala-gejala fsikis yang terjadi di TGA Bookstre Galaxi Mal Surabaya. Hal tersebut dimaksudkan untuk mengamati langsung apakah kejadian-kejadian tersebut akan berbeda jauh atau relevan dengan hasil-hasil penelitian yang diperoleh dari hasil wawancara.

Prosedur Pengumpulan Data

Dalam penelitian kualitatif, peneliti sekaligus berfungsi sebagai instrument utama yang terjun kelapangan serta berusaha sendiri mengumpulkan data melalui observasi maupun wawancara dan interview secara lebih rinci teknik pengumpulan data yang dipergunakan dalam penelitian ini adalah:

\section{Metode Observasi (Pengamatan).}

Pengamatan adalah alat pengumpulan data yang dilakukan dengan cara mengamati dan mencatat secara sistimatik gejala-gejala yang diselidiki. (Supardi, 2006: 88). Senada dengan itu Yehoda dkk, (2006: 89) menjelaskan pengamatan akan menjadi alat pengumpulan data yang baik apabila: 

a) Mengabdi pada tujuan penelitian
b) Direncanakan secara sistematik
c) Dicatat dan dihubungkan dengan proposisi-prosposisi yang umum
d) Dapat dicetak dan dikontrol validitas, relibilitas, dan ketelitianya.

\section{Metode Interview}

Metode ini disebut juga dengan metode wawancara, yaitu suatu metode pengumpulan data yang dilakukan melalui Tanya jawab secara langsung dengan sumber data.

Sehungan dengan hal ini Margono (2003: 165) mengemukakan bahwa: "interview merupakan alat pengumpulan informasi dengan cara mengajukan pertanyaan secara lisan, untuk dijawab secara lisan juga, cirri utama dari interview adalah kontak langsung dengan tatap muka antara pencari informasi dengan sumber informasi”.

Analisis data penelitian kualitatif pada dasarnya sudah dilakukan sejak awal kegiatan penelitian sampai akhir penelitian. Dengan cara ini diharapkan terdapat konsistensi analisis data secara keseluruhan. Karena mengingat penelitian ini bersifat deskriptif, maka digunakan analisa data filosofis atau logika yaitu analisa induktif.

Metode induktif adalah metode berpikir dengan mengambil kesimpulan dari data-data yang bersifat khusus. Sebagai mana yang telah dijelaskan oleh Sutrisno, yaitu: Berfikir induktif berangkat dari fakta-fakta yang khusus, peristiwa-peristiwa yang kongkrit, kemudian dari faktafakta atau peristiwa-peristiwa yang khusus, kongkrit itu ditarik generalisasi-generalisasi yang mempunyai sifat umum”. (Sutrisno, 1986: 42)

Dalam penelitian ini digunakan metode induktif untuk menarik suatu kesimpulan terhadap hal-hal atau peristiwa-peristiwa dari data yang telah dikumpulkan melalui observasi, wawancara, dan dokumentasi, yang bisa digeneralisasikan (ditarik kearah kesimpulan umum), maka jelas metode induktif ini untuk menilai fakta-fakta empiris yang ditemukan lalu dicocokan dengan teori-teori yang ada. 


\section{PEMBAHASAN}

Terkait dengan tinjauan teoritis yang telah dibahas pada pembahasan sebelumnya, maka pada pembahasan kali ini akan dibahas mengenai sejarah terbentuknya PT. Kaldu Sari Nabati, kepemimpinan di PT. Kaldu Sari Nabati, kinerja karyawan di PT. Kaldu Sari Nabati dan peningkatan kinerja di PT. Kaldu Sari Nabati . Adapun penjelasan lebih lanjut akandibahas sebagai berikut.

\subsection{Sejarah PT. Kaldu Sari Nabati}

PT. Kaldu Sari Nabati merupakan perusahaan yang bergerak di bidang makanan dan minuman ringan yakni :

1. Richeese

2. Richoco

3. Nabati wafer

4. Ahh

5. Siip

6. Rols

7. Pasta

8. Bisvit selimut

PT Kaldu Sari Nabati Indonesia merupakan unit bisnis rintisan awal dari Nabati Group. Sejumlah merek produk yang telah banyak dikenal konsumen, antara lain Richeese dan Richoco. Produk-produk tersebut merupakan hasil perpaduan antara bahan baku pilihan dengan proses produksi yang modern sehingga menghasilkan produk berkualitas dan bergizi.

Proses produksi yang dilakukan juga telah memenuhi standar ISO dan GMP. Berbagai keunggulan itu pula yang mengantarkan produk KSNI menjadi pilihan utama konsumen. Hal ini dibuktikan dengan diraihnya sejumlah penghargaan, seperti Best Brand Award, MURI, dan Top Brand Award. 
Visi

Meningkatkan kualitas hidup masyarakat melalui produksi makanan dan minuman berkualitas yang inovatif dan berorientasi pada kebutuhan konsumen serta didukung oleh sumber daya manusia yang kompeten untuk menghasilkan nilai tambah bagi para stakeholder.

Misi

Berinovasi dalam menghasilkan makanan dan minuman bergizi serta berkualitas untuk memberikan nilai tambah setiap tahap kehidupan manusia.

TABEL STRATEGI \& MOTTO PERUSAHAAN

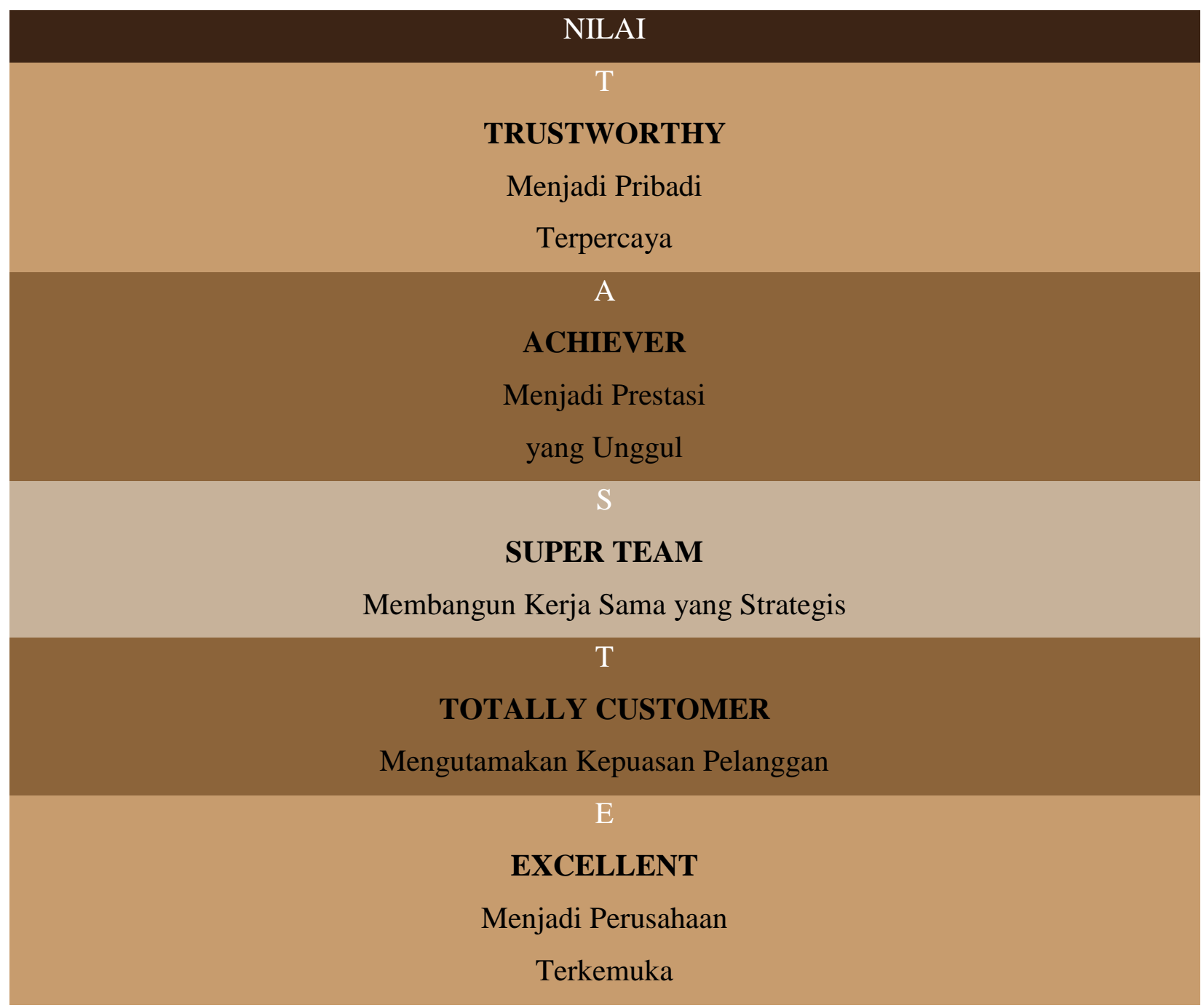




\subsection{Gaya Kepemimpinan}

Dalam hal ini penulis mengambil contoh gaya kepemimpinan seorang area manager PT. Kaldu Sari Nabati Surabaya yakni Bpk. Alfon sious dalam kinerjanya beliau menekankan pada karyawan agar mampu meningkatkan penjualan dan meningkatkan efektifitas kerja karyawan dibawahnya. Kebijakan beliau dalam menekankan pelaporan oleh karyawan terhadap omset yang di dapat setiap harinya beliau membuat program "Upselling by operation" untuk meningkatkan hasil penjualan dan memberikan solusi terhadap penjualan dan di berlakukan terhadap semua karyawan yang beroperasi di lapangan. Dengan membangun koordinasi yang berkesinambungan dengan karyawan memotivasi kinerja dan memberikan reward terhadap hasil pencapaian penjualan bertujuan untuk memberikan evaluasi kinerja karyawan.

\subsection{Kinerja Karyawan}

Ukuran secara kualitatif dan kuantitatif yang menunjukkan tingkatan pencapaian suatu sasaran atau tujuan yang telah ditetapkan adalah merupakan sesuatu yang dapat dihitung serta digunakan sebagai dasar untuk menilai atau melihat bahwa kinerja setiap hari dalam perusahaan dan perseorangan terus mengalami peningkatan sesuai dengan rencana yang telah ditetapkan. Dan Manager area menerapkan reward for best sales agar dapat memotivasi kinerja karyawan PT. Kaldu Sari Nabati. 
TABEL UPSELLING KARYAWAN (Per Hari)

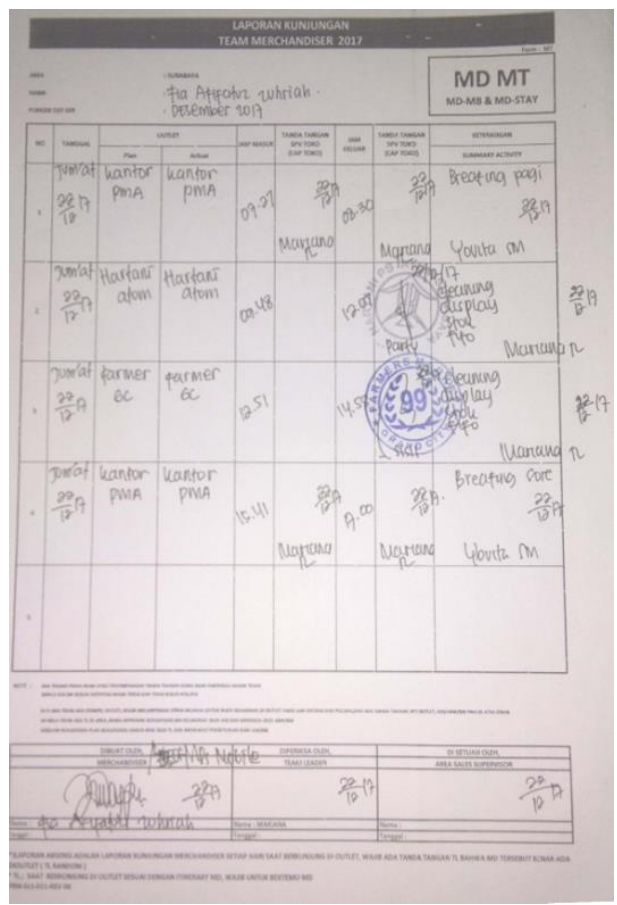

TABEL UPSELLING KARYAWAN (Per Bulan)

\begin{tabular}{|c|c|c|c|c|c|c|c|c|c|c|c|c|c|c|c|c|}
\hline \multirow[t]{2}{*}{ SALESMAN } & \multirow[b]{2}{*}{ reT } & \multirow[b]{2}{*}{ REAL } & \multirow[b]{2}{*}{ \% } & \multirow[b]{2}{*}{ TGT } & \multirow[b]{2}{*}{ REAL } & \multirow[b]{2}{*}{ * } & \multirow[b]{2}{*}{ RO } & \multirow[b]{2}{*}{ ROA } & \multirow[b]{2}{*}{ * } & \multirow[b]{2}{*}{ sc } & \multirow[b]{2}{*}{ EC } & \multirow[b]{2}{*}{ * } & \multirow[b]{2}{*}{ TGT IPT } & \multirow[b]{2}{*}{ IPT } & \multirow[b]{2}{*}{$\begin{array}{l}\text { IML } \\
\text { mEM }\end{array}$} & \multirow[b]{2}{*}{$\begin{array}{c}\mathbf{5} \\
\text { ROA }\end{array}$} \\
\hline & & & & & & & & & & & & & & & & \\
\hline AND TOTAL CABANG & 6.240 & 2.567 & 41,1 & 777.648 .191 & 339.344 .409 & 43,6 & 201 & 166 & 82,6 & 527 & 333 & 63,2 & 9,0 & 6,8 & 2249 & 75.0 \\
\hline MSA-YURITA WIDYASTUT & 186 & 121 & 64,9 & 23.120 .023 & 16.556 .129 & 71,6 & 1 & 1 & 100,0 & 5 & 5 & 100,0 & 21 & 12 & 21 & 57,1 \\
\hline IMA-TAחIK ALFIANI & 576 & 519 & 90,1 & 74.575 .614 & 69.605 .323 & 93,3 & 118 & 96 & 81,4 & 227 & 129 & 56,8 & 9 & 10 & 1252 & 107,8 \\
\hline MMAEELOK SISWANT & 454 & 118 & 26,1 & 56.426 .751 & 15.117 .820 & 26,8 & 6 & 5 & 83,3 & 22 & 16 & 72,7 & 17 & 7 & 82 & 41,2 \\
\hline MMAFIA & 105 & 51 & 48,3 & 12.822 .532 & 6.911 .733 & 53,9 & 6 & 4 & 66,7 & 22 & 14 & 63,6 & 16 & 5 & 44 & 30,1 \\
\hline MMA-NEVI OKTAVIANT & 272 & 122 & 45,0 & 33.472 .415 & 16.268 .614 & 48,6 & 5 & 5 & 100,0 & 24 & 13 & 54,2 & 22 & 14 & 104 & 65,1 \\
\hline MSA-AYU & 440 & 233 & 53,0 & 55.834 .239 & 27.035 .358 & 48,4 & 1 & 1 & 100,0 & 4 & 4 & 100,0 & 23 & 19 & 42 & 82,6 \\
\hline MMA-VACANT & 238 & $\therefore$ & & 29.448 .979 & & & -1 & -1 & & - & . & & & & & \\
\hline MMA-MARISA & 73 & 185 & 253,8 & 9.770 .764 & 24.934 .808 & 255,2 & 1 & 1 & 100,0 & 4 & 5 & 125,0 & 3. & 3 & 11 & 100,0 \\
\hline MMA-UPIK & 270 & 131 & 48,4 & 33.363 .322 & 18.553 .366 & 55,6 & 6 & 6 & 100,0 & 27 & 20 & 74,1 & 19 & 7 & 100 & 36,6 \\
\hline MMA-UMI MASKURIYAH & 223 & 111 & 49,9 & 27.062 .690 & 13.907.072 & 51,4 & 6 & 6 & 100,0 & 26 & 9 & 34,6 & 17 & 9 & 66 & 52,2 \\
\hline MMA-ERINA & 305 & 230 & 75,4 & 37.173 .449 & 29.578 .398 & 79,6 & 5 & 5 & 100,0 & 22 & 20 & 90,9 & 13 & 8 & 83 & 63,5 \\
\hline MMA-VACANT2 & 378 & $\cdot$ & & 48.487 .641 & & & $\cdot$ & $\cdot$ & & - & -1 & & & & & \\
\hline MSA-JUMAIYA & 81 & 9 & 11,1 & 10.241 .027 & 1.534 .199 & 15,0 & 1 & 1 & 100,0 & 5 & 3 & 60,0 & 20 & 6 & 8 & 30,0 \\
\hline MSA-MAERIA & 297 & 24 & 8,0 & 36.279 .464 & 3.398 .998 & 9,4 & 1 & 1 & 100,0 & 5 & 3 & 60,0 & 21 & 6 & 13 & 28,6 \\
\hline MSAASIH & 328 & 60 & 18,2 & 39.771 .955 & 8.127 .730 & 20,4 & 1 & 1 & 100,0 & 5 & 3 & 60,0 & 21 & 14 & 27 & 66,7 \\
\hline MSA-SULAIMAN & 315 & 109 & 34,4 & 37.461 .040 & 12.757 .108 & 34,1 & 1 & 1 & 100,0 & 5 & 4 & 80,0 & 24 & 20 & 36 & 83,3 \\
\hline MMA-TRI YULLLANING SIH & 165 & 88 & 53,4 & 21.993 .693 & 11.596 .497 & 52,7 & 8 & 5 & 62,5 & 22 & 11 & 50,0 & 22 & 8 & 77 & 35,8 \\
\hline MMA-ARDHA & 387 & 88 & 22,8 & 47.050 .455 & 11.035 .779 & 23,5 & 5 & 4 & 80,0 & 17 & 13 & 76,5 & 15 & 7 & 53 & 45,7 \\
\hline MSA-EKY REMAYANTI & 174 & 18 & 10,5 & 21.265 .400 & 2.852 .502 & 13,4 & 1 & 1 & 100,0 & 4 & 4 & 100,0 & 20 & 11 & 19 & 55,0 \\
\hline MMA-SANTI & 279 & 74 & 26,4 & 36.356 .108 & 10.019 .153 & 27,6 & 5 & 4 & 80,0 & 22 & 14 & 63,6 & 14 & 6 & 55 & 42,0 \\
\hline MMA-VIITA & 125 & 67 & 53,7 & 15.070 .207 & 10.058 .088 & 66,7 & 5 & 4 & 80,0 & 22 & 15 & 68,2 & 16 & 7 & 59 & 43,1 \\
\hline MMA-VACANT2 & 9 & 57 & 633,5 & 1.078 .564 & 7.828 .495 & 725,8 & 5 & 5 & 100,0 & & & & 18 & 5 & & 29,6 \\
\hline MMA-YUNI & 133 & 28 & 21,0 & 17.009 .725 & 3.087 .781 & 18,2 & 7 & 4 & 57,1 & 18 & 8 & 44,4 & 24 & 8 & 19 & 33,3 \\
\hline MMA-YIRMIATI & 72 & 19 & 26,1 & 8.813 .655 & 2.705 .845 & 30,7 & 1 & 1 & 100,0 & 5 & 4 & 80,0 & 20 & 11 & 15 & 55,0 \\
\hline MMA-DINA JAYANTI & 93 & 34 & 36,5 & 11.414 .762 & 4.931.705 & 43,2 & 2 & 1 & 50,0 & 4 & 4 & 100,0 & 20 & 11 & 13 & 55,0 \\
\hline MMA-NICO YANUAR & 127 & 25 & 19,9 & 15.779 .428 & 4.082 .404 & 25,9 & 2 & 2 & 100,0 & 5 & 6] & 120,0 & 20 & 5 & 21. & 25,0 \\
\hline MSA.ANGGA & 135 & 47 & 34,9 & 16.504 .289 & 6.859 .504 & 41,6 & 1 & 1 & 100,0 & 5) & 6) & 120,01 & 20 & 14 & 29 | & 70,01 \\
\hline Rekap per Sales & Caban & & & & & & & & & & & $f$ & & & & \\
\hline
\end{tabular}




\section{KESIMPULAN}

Gaya kepemimpinan yang memiliki suatu penekanan namun dengan diimbangi suatu komunikasi dalam organisasi yang baik , mampu memberikan pengaruh positif terhadap kinerja karyawan sebuah perusahaan untuk mencapai sebuah tujuan. Pemgambilan keputusan merupakan proses memilih sejumlah alternatif penting bagi pemimpin, karena proses pengambilan keputusan mempunyai peran penting dalam memotivasi kepemimpinan, komunikasi, koordinasi, dan perubahan perusahaan yang dilakukan oleh seorang pemimpin pada perusahaan yang dia pimpin. Pengambilan keputusan juga bisa dipandang sebagai proses memilih dari berbagai alternatif untuk memecahkan masalah dalam rangka pencapaian tujuan sebuah perusahaan.

Pengambilan keputusan yang efektif perlu dilakukan oleh seorang pemimpin dalam sebuah perusahaan. Dalam pengambilan keputusan seorang pemimpin harus memperhatikan berbagai aspek, misalnya perlu memperhatikan situasi dan kondisi, memperhatikan berbagai model, gaya, proses dan tidak kalah pentingnya perlu memperhatikan metode serta tahapantahapan secara sistematis. Sebab proses pengambilan keputusan selalu terkait dengan proses memilih dari berbagai alternatif. 


\section{DAFTAR PUSTAKA}

Alimudin, Arasy, and Agus Sukoco. "The Leadership Style Model That Builds Work Behavior Through Organizational Culture." JURNAL LENTERA: Kajian Keagamaan, Keilmuan Dan Teknologi 3.2 (2017): 362-375.

APA

Alimudin, A., \& Sukoco, A. (2017). The Leadership Style Model That Builds Work Behavior Through Organizational Culture. JURNAL LENTERA: Kajian Keagamaan, Keilmuan Dan Teknologi, 3(2), 362-375.

ISO 690

ALIMUDIN, Arasy; SUKOCO, Agus. The Leadership Style Model That Builds Work Behavior Through Organizational Culture. JURNAL LENTERA: Kajian Keagamaan, Keilmuan Dan Teknologi, 2017, 3.2: 362-375.

Wibawa, Edy . (2006) Pengaruh Model Kepemimpinan dan Kepuasan Kerja terhadap Kinerja Pegawai pada Kantor imigrasi Jakarta Selatan

. Program Pascasarjana Universitas Indonesia.

Malayahati. (2010). I'm The Boss. Yogyakarta. Jogja . Bangkit publisher. 